\title{
KOMPETISI DAN EFISIENSI PADA PENGADAAN PEMERINTAH: BUKTI EMPIRIS PADA KEMENTERIAN/LEMBAGA DI INDONESIA
}

\author{
Billy Thandy Tulungen \\ Pemerintah Provinsi Sulawesi Utara \\ Vid Adrison \\ Universitas Indonesia \\ Alamat Korespondensi: billy.thandy@alumni.ui.ac.id
}

\begin{abstract}
This study investigates the effect of the number of bidders in the final evaluation stage before determining the winner on the ratio of the winning bidder price and the estimated price (HPS) on the tender and selection packages of ministries/institutions in Indonesia. This study used 82,560 cross-sections data on tender and selection packages obtained using website scraping technique on 49 LPSE websites of Ministries/Institutions in Indonesia from 2008 to March 2020. To determine this effect, this study used the OLS and IV-2SLS methods to reduce the potential for bias due to endogeneity. This study found an effect of the number of bidders in the final evaluation stage on the ratio of the winning bidder price and HPS, which would reduce the ratio by 0.0335 units or save procurement spending through tender or selection by 3.35 percent on the value of HPS. In addition, we also found that there was an indirect effect on the value of the procurement package, the prequalification method and the evaluation pattern on the number of bidders in the final evaluation stage prior to determination of the winner.
\end{abstract}

\begin{abstract}
ABSTRAK
Penelitian ini menginvestigasi pengaruh jumlah peserta pemilihan pada tahap evaluasi terakhir sebelum penetapan pemenang terhadap rasio harga penawaran pemenang dan HPS pada paket tender dan seleksi pada kementerian/lembaga di Indonesia. Penelitian ini menggunakan 82,560 data cross-section paket tender dan seleksi yang diperoleh dengan menggunakan teknik website scraping pada 49 website LPSE Kementerian/Lembaga di Indonesia pada tahun 2008 sampai dengan bulan Maret 2020. Untuk mengetahui pengaruh tersebut, penelitian ini menggunakan metode OLS dan metode IV-2SLS untuk mengurangi potensi bias akibat endogeneity. Penelitian ini menemukan adanya pengaruh dari jumlah peserta pemilihan tahap evaluasi terakhir terhadap rasio harga penawaran pemenang dan HPS, yang mana akan mengurangi rasio sebesar 0.0335 satuan atau menghemat belanja pengadaan melalui tender atau seleksi sebesar 3.35 persen terhadap nilai HPS. Selain itu, kami juga menemukan adanya pengaruh tidak langsung dari nilai paket pengadaan, metode prakualifikasi dan pola evaluasi terhadap jumlah peserta pemilihan pada tahap evaluasi terakhir sebelum penetapan pemenang.
\end{abstract}

KATA KUNCI:

Pengadaan Pemerintah, Efisiensi, Competitive Bidding

KLASIFIKASI JEL:

D44, H50, H57, 022

CARA MENGUTIP:

Tulungen, B. T. \& Adrison, V. (2021). Kompetisi dan efisiensi pada pengadaan pemerintah: bukti empiris pada kementerian/lembaga di indonesia. Indonesian Treasury Review: Jurnal Perbendaharaan, Keuangan Negara dan Kebijakan Publik, 6(1), 19 - 29. 


\section{PENDAHULUAN}

\subsection{Latar Belakang}

Di beberapa negara, sebagian besar proporsi belanja pemerintah diimplementasikan melalui pengadaan barang/jasa pemerintah (PBJ). Sebagai contoh, rata-rata belanja pengadaan publik di negara-negara anggota OECD diperkirakan sebesar 13 persen dari Produk Domestik Bruto (PDB) dan 29 persen dari belanja pemerintah (OECD, 2016). Di Indonesia, belanja pengadaan barang/jasa menyumbang proporsi yang signifikan sebesar 54 persen dari belanja kementerian, lembaga dan pemerintah daerah, atau senilai Rp1.039 triliun (LKPP, 2019).

Pengadaan pemerintah di Indonesia diatur dalam Peraturan Presiden Nomor 16 Tahun 2018 yang mengganti Peraturan Presiden Nomor 54 Tahun 2010 dan perubahannya. Regulasi pengadaan mengatur bahwa pemerintah melalui pokja pemilihan akan mengevaluasi pelaku usaha yang mengikuti tender dan seleksi baik dalam hal kemampuan pelaku usaha menyediakan barang jasa dan barang jasa yang ditawarkan sesuai dengan persyaratan yang telah ditetapkan sebelumnya. Sebelum penetapan pemenang, pelaku usaha akan melalui beberapa tahapan evaluasi baik evaluasi kualifikasi untuk mengevaluasi kualifikasi penyedia, dan evaluasi administrasi, teknis, dan harga untuk mengevaluasi barang jasa yang ditawarkan. Pengguna jasa dalam hal ini Pejabat Pembuat Komitmen (PPK) sebelum proses tender atau seleksi terlebih dahulu menetapkan nilai Harga Perkiraan Sendiri (HPS) yang menjadi batas atas harga penawaran pada tender dan seleksi, sehingga pelaku usaha yang ingin menawar harus menawar di bawah atau sama dengan nilai HPS. Pelaku usaha yang menawar di bawah nilai HPS dengan harga yang terendah ataupun bobot tertinggi (dalam metode evaluasi kombinasi bobot teknis dan harga) yang ditetapkan sebagai pemenang

Dalam penelitian ini dilakukan pengujian secara empiris atas efek dari lingkungan kompetitif (jumlah peserta pada tahap evaluasi terakhir sebelum penetapan pemenang) terhadap rasio nilai penawaran pemenang dan HPS (Harga Perkiraan Sendiri) - sering didefinisikan sebagai relative bid dalam beberapa literatur (De Silva et. al., 2009; Ishii, 2009; Padhi \& Mohapatra, 2011) - dengan menggunakan set data unik yang dipublikasikan pada website LPSE (Layanan Pengadaan secara Elektronik) Kementerian/Lembaga di Indonesia.

Studi empiris tentang competitive bidding pada tender/seleksi pengadaan pemerintah, terutama pada negara berkembang masih terbatas. Hal ini disebabkan karena masih terbatasnya akses data tender/seleksi pengadaan pemerintah ataupun belum diterapkannya sistem pengadaan secara elektronik. Sebagian besar negara maju yang memiliki data yang komprehensif dan tersedia bagi publik, telah menerapkan sistem $e$ procurement (Jääskeläinen \& Tukiainen, 2019; İ. Onur, Özcan, \& Taş, 2012 Gupta, 2002). Di Indonesia sejak berlakunya Peraturan Presiden Nomor 4 Tahun 2015 yang kemudian diganti dengan Peraturan Presiden Nomor 16 Tahun 2018 tentang Pengadaan Barang Jasa Pemerintah, negara mewajibkan bagi instansi pemerintah yang termasuk dalam ruang lingkup aturan tersebut untuk melaksanakan tender dan seleksi secara elektronik. Artinya, setiap instansi pemerintah di Indonesia wajib mengunggah semua informasi tentang pengadaan pemerintah pada Sistem Pengadaan Secara Elektronik baik pada situs web Sistem Informasi Rencana Umum Pengadaan (SIRUP) maupun situs web LPSE, walaupun tidak semua data dapat diakses publik.

Meskipun studi tentang tender/seleksi telah dibahas secara luas dalam berbagai literatur, belum ada studi yang meneliti tentang efek peningkatan jumlah peserta pemilihan pada tahap evaluasi akhir sebelum penetapan pemenang pada tender/seleksi terhadap rasio nilai penawaran pemenang dan HPS. Penelitian sebelumnya terkait rasio harga penawaran pemenang dan estimated price (Porter \& Zona, 1993; Bajari \& Ye, 2003; Estache \& Iimi, 2008; Iimi, 2006; Ishii, 2009; Onur, Özcan, \& Taş, 2012; Onur \& Tas, 2019) menguji bagaimana efek kompetisi terhadap harga penawaran dengan melihat dari sisi jumlah partisipasi peserta pemilihan pada tahap pertama atau yang mendaftar pada proses tender/seleksi. Namun, literatur-literatur tersebut belum dapat menjelaskan efek dari kompetisi atau jumlah peserta pemilihan pada tahap sebelum penetapan pemenang terhadap rasio tersebut. Pada tahap evaluasi sebelum penetapan pemenang, jumlah peserta pemilihan dapat berbeda dengan peserta pada tahap pertama, karena telah melalui beberapa tahapan evaluasi. Oleh karena itu, kemungkinan akan terjadi perbedaan hasil ketika menguji jumlah peserta pemilihan pada tahap evaluasi sebelum penetapan pemenang.

Penelitian ini menganalisis set data unik paket tender dan seleksi pengadaan barang jasa pemerintah di Indonesia pada periode antara tahun 2008 sampai dengan bulan Maret 2020. Data ini dipublikasikan pada website Layanan Pengadaan Secara Elektronik (LPSE) Kementerian/Lembaga di Indonesia. Data ini berisi semua jenis pengadaan pemerintah pada semua otoritas publik (seperti kementerian, lembaga, pemerintah daerah dan otoritas publik lainnya yang melakukan pengadaan pemerintah). Sepengetahuan kami, penelitian ini adalah penelitian pertama yang menggunakan set data unik yang komprehensif dalam menganalisis 
competitive bidding pada tender/seleksi dan meneliti dari sisi jumlah peserta pemilihan pada tahap evaluasi sebelum penetapan pemenang.

\subsection{Gambaran Umum Pengadaan Pemerintah di Indonesia}

Pemerintah Indonesia melakukan intervensi di sektor pengadaan pemerintah yang bersumber pada APBN atau APBD. Intervensi yang dilakukan dengan meregulasi pengadaan pemerintah melalui Peraturan Presiden. Peraturan ini telah beberapa kali mengalami perubahan dan perubahan terakhirnya pada Peraturan Presiden Nomor 16 Tahun 2018. Pada peraturan ini, terdapat beberapa perubahan baik nomenklatur, threshold, metode pemilihan dan lain-lain.

Terdapat dua pembagian masa perubahan aturan pengadaan pemerintah di Indonesia, yaitu sebelum tahun 2018 dan setelah tahun 2018.

\section{Sebelum Tahun 2018}

Sebelum Peraturan Presiden Nomor 16 Tahun 2018 berlaku, Pemerintah menetapkan batas pagu anggaran yang pengadaannya melalui proses lelang, yang mana untuk pengadaan non konsultansi dilaksanakan proses lelang ketika pagu anggaran paling sedikit diatas Rp200.000.000, dan jasa konsultansi dengan pagu anggaran paling sedikit diatas Rp50.000.000.

Selain itu, sebelum berlakunya Peraturan Presiden Nomor 16 Tahun 2018, Pemerintah mengatur pula metode evaluasi dengan mengkombinasikan bobot teknis dan bobot harga. Pada pengadaan non-konsultansi, ditetapkan kombinasi bobot teknis 10 s.d. 30 persen dan bobot harga 70 s.d. 90 persen. Sedangkan pada pengadaan jasa konsultansi, yang juga menggunakan kombinasi bobot teknis 60 s.d. 80 persen, dan bobot harga 20 s.d. 40 persen. Dari kedua jenis pengadaan tersebut, menunjukan adanya perbedaan penilaian pembobotan, dimana pada pengadaan non-konsultansi lebih menekankan bobot harga dibandingkan pengadaan jasa konsultansi yang menekankan bobot teknis atau aspek kualitas.

\section{Setelah Tahun 2018}

Kemudian setelah berlakunya Peraturan Presiden Nomor 16 Tahun 2018, terjadi perubahan nomenklatur dari lelang menjadi seleksi. Selain itu, proses seleksi pada Jasa Konsultansi meningkat menjadi Rp100.000.000. Disamping itu, pada Peraturan Presiden Nomor 16 Tahun 2018 terjadi perubahan bobot teknis dan harga. Pada metode evaluasi pengadaan non-konsultansi kombinasi bobot teknis dan harga mengalami perubahan dengan bobot teknis 60 s.d. 70 persen, dan bobot harga 30 s.d. 40 persen. Hal ini menunjukan bahwa pemerintah lebih menekankan dalam aspek kualitas teknis pada pengadaan non-konsultansi.
Hal ini berbeda dengan aturan sebelumnya dimana pemerintah lebih menitikberatkan aspek harga dibandingkan aspek teknis pada metode evaluasi yang menggunakan pengkombinasian bobot teknis dan harga pada pengadaan non-konsultansi.

Secara garis besar, peserta pemilihan pada tender dan seleksi di Indonesia akan melalui beberapa tahapan evaluasi yaitu evaluasi kualifikasi, administrasi, teknis dan harga. Proses evaluasi ini untuk memastikan pemilihan penyedia barang/jasa dilakukan dengan menggunakan kriteria yang telah ditetapkan sebelum membuat rekomendasi pemenang. Hal tersebut dilakukan dengan cara meneliti kelengkapan persyaratan yang disampaikan peserta pemilihan penyedia barang/jasa sesuai dengan yang ditetapkan dalam dokumen pengadaan, menilai dan menetapkan apakah penawaran yang disampaikan memenuhi atau tidak memenuhi persyaratan dan ketentuan dokumen pengadaan, dan menyusun peringkat peserta yang memenuhi persyaratan dengan cara memberikan nilai terhadap dokumen penawaran yang disampaikan.

\section{LANDASAN TEORI}

Konsep Competitive Bidding berkaitan konsep kompetisi dan auction theory. Organization theory secara tradisional memperkenalkan bahwa semakin banyak jumlah firma penyedia barang/jasa pada suatu pasar, maka harga yang dihasilkan akan lebih murah. (Wolfstetter, 2000). Dalam auction theory, Auction menjadi mekanisme dalam penawaran dimana memiliki aturannya sendiri dalam menentukan pemenang. Aturan tersebut dapat mempengaruhi partisipasi, penawaran dan perilaku dari penawar (Wolfstetter, 2000).

Walaupun studi tentang lelang/tender telah banyak dilakukan, tetapi masih belum terdapat literatur yang membahas tentang efek dari bertambahnya jumlah peserta pemilihan pada tahap evaluasi terakhir sebelum penetapan pemenang terhadap hasil dari tender/seleksi pengadaan.

Secara teoritis, Matthews (1987), dan McAfee \& McMillan (1987) mempertimbangkan bahwa penawar akan menghadapi informasi asimetris atas pesaingnya. Dalam setting tender/seleksi, penawar mengalami informasi asimetris terhadap pesaingnya baik dalam hal kapasitas, pengalaman, finansial, sumber daya dan proposal penawaran peserta lelang. Hal ini dapat menjadi insentif bagi peserta lelang untuk melakukan koordinasi atau bahkan melakukan kolusi membentuk bidding rings sehingga harga yang ditawarkan meningkat. Hal berbeda akan terjadi ketika peserta lelang bertambah banyak, peserta lelang akan sulit 
berkoordinasi karena biaya untuk memperoleh informasi dan biaya koordinasi yang meningkat.

Dalam proses lelang, terdapat dua tipe evaluasi penawaran - harga terendah dan scoring rule. Scoring rule tidak hanya mempertimbangkan harga tetapi juga teknis yang ditawarkan penawar dalam mengevaluasi penawaran, dimana pemenang lelang ditentukan dari bobot tertinggi dari kombinasi skor teknis dan harga. Studi menunjukan bahwa seorang penawar lebih efektif meningkatkan utility-nya ketika menggunakan evaluasi harga terendah dibandingkan scoring rule. Hal ini dikarenakan sinyal memperoleh informasi harga penawaran lebih mudah pada evaluasi harga terendah dibandingkan dengan scoring rule yang juga mempertimbangkan unsur teknis pada penilaian penawaran. Namun dengan menggunakan scoring rule, juru lelang memperoleh expected profit yang lebih tinggi dibandingkan menggunakan harga terendah (Asker \& Cantillon, 2008; Bichler, 2000; Che, 1993; Chen-Ritzo, Harrison, Kwasnica, \& Thomas, 2005; Ondestal \& Van de Meerendonk, 2008). Karena penawar menghadapi informasi asimetris dan sulitnya memperoleh sinyal atas penawaran teknis dan harga pesaingnya, maka penawar akan menawarkan harga penawaran yang lebih rendah sehingga juru lelang memperoleh keuntungan lebih besar dari evaluasi harga terendah.

Studi teoritis yang dikemukakan oleh Fan \& Wolfstetter (2008) membangun sebuah model game lelang pengadaan sederhana, dimana kontraktor memiliki dua biaya; biaya dalam pelaksanaan kontrak dan biaya dalam mempersiapkan penawaran. Mereka mempertimbangkan bahwa biaya mempersiapkan penawaran akan costly. Hal ini terjadi jika penawaran tersebut bersifat teknikal, yang mengakibatkan peserta lelang harus merekrut estimator professional untuk mengestimasi biaya penawaran yang sesuai dengan kemampuan peserta lelang, khususnya untuk pekerjaan yang kompleks.

Secara empiris, Onur, Özcan \& Tas (2012), Estache \& Iimi, (2008), dan Iimi (2006) menunjukan bahwa lingkungan yang kompetitif pada tahap awal pendaftaran penawar dapat meningkatkan efektifitas pengadaan pemerintah. Mereka berkesimpulan bahwa terdapat hubungan negatif antara jumlah peserta yang mendaftar dan harga penawaran pemenang. Disisi lain, Porter \& Zona (1993), dan Bajari \& Ye (2003) menemukan bahwa ketika peserta lelang melakukan kolusi dengan sesama peserta lelang maka harga penawarannya menjadi meningkat. Ketika terdapat perilaku koruptif seperti penyuapan kepada birokrat juru lelang, maka harga penawarannya cenderung juga meningkat (Compte, O., LambertMogiliansky, A., \& Verdier, T., 2005).

\section{METODOLOGI PENELITIAN}

\subsection{Data}

Penelitian ini menggunakan data tender dan seleksi pada website LPSE Kementerian Lembaga di Indonesia. Kami memperoleh data tersebut dengan menggunakan teknik website scraping. Dari 60 website LPSE Kementerian/Lembaga yang terdaftar di LKPP, kami berhasil memperoleh data dari 49 website LPSE, sedangkan sisanya (dengan teknik website scraping) tidak dapat kami peroleh atau status gagal scrape. Dari 49 LPSE tersebut, kami memperoleh 82,560 paket tender dan seleksi yang akan menjadi unit observasi pada penelitian ini. Tentunya jumlah paket tender dan seleksi ini belum secara spesifik dan keseluruhan menggambarkan kondisi tender dan seleksi pada kementerian/lembaga di Indonesia karena terdapat website LPSE yang gagal di-scraping, serta adanya keterbatasan waktu penelitian sehingga kami menggunakan data pada website LPSE yang berhasil di-scraping. Data paket tender dan seleksi ini berisi informasi berupa kode paket, nama paket, nilai pagu anggaran, nilai HPS, metode evaluasi, metode penilaian kualifikasi, jenis pengadaan, peserta pemilihan yang mengikuti paket tersebut, nama pemenang, alamat pemenang dan harga penawaran. Data ini merupakan data yang dipublikasi pada website LPSE dan terbuka bagi publik.

\subsection{Strategi Empiris}

Penelitian ini menggunakan metode OLS (Ordinary Least Square) untuk mengetahui efek lingkungan kompetitif pada pengadaan pemerintah. Adapun model empiris yang digunakan pada metode OLS ini adalah sebagai berikut

$$
\text { Ratio }_{i t}=\frac{\text { winbid }_{i t}}{\text { estimate }_{i t}}=\alpha_{0}+\alpha_{1} N_{i t}+\delta X_{i t}+\varepsilon_{i t}
$$

Dimana estimate adalah HPS, winbid merupakan harga penawaran pemenang, $\mathrm{N}$ merupakan jumlah peserta pemilihan dan $\mathrm{X}$ merupakan variabel kontrol karakteristik paket pengadaan. Nilai Ratio yang tinggi berarti bahwa harga penawaran pemenang berada dekat dengan nilai HPS, sedangkan nilainya yang rendah akan menunjukan bahwa tender/seleksi lebih ekonomis ditinjau dari perspektif pemerintah.

Tantangan utama dalam menjawab penelitian ini adalah potensi permasalahan endogeneity pada variabel yang digunakan pada penelitian ini. Pada variabel penjelas, jumlah peserta pemilihan diduga berhubungan dengan nilai paket pengadaan, pola evaluasi dan penilaian prakualifikasi. Hal ini dikarenakan peserta pemilihan yang mengikuti tender akan melihat terlebih dahulu apabila nilai paket pengadaannya telah sesuai dengan kemampuannya. Selain itu, jumlah peserta 
pemilihan akan tergantung pada tahapan evaluasi dan tahapan prakualifikasi yang telah diikuti oleh peserta pemilihan. Hal ini menyebabkan variabel penjelas bersifat endogen, sehingga akan menghasilkan estimasi hasil yang bias. Untuk mengurangi potensi permasalahan tersebut, penelitian ini menggunakan strategi empiris yaitu: Instrumental Variable (IV).

Untuk mengurangi permasalahan endogeneity yang kemungkinan muncul, dan kemungkinan hasil estimasi yang bias dari OLS, penelitian ini menggunakan metode Instrumental Variable with Two Stage Least Square (IV-2SLS). Dalam penelitian ini, variabel jumlah peserta pemilihan pada tahap evaluasi terakhir akan diinstrumenkan dengan variabel lain sebagai tahap pertama. Variabel yang digunakan sebagai instrumen adalah penilaian kualifikasi, pola evaluasi dan size paket pengadaan (nilai HPS). Dengan menggunakan metode IV-2SLS, maka model regresi tahap pertama dapat ditulis sebagai berikut:

$N_{i t}=\gamma_{0}+\gamma_{1}$ estimate $_{i t}+$

$$
\begin{aligned}
& \gamma_{2} \text { prequalification_dummy } y_{i t}+ \\
& \gamma_{3} \text { athk_dummy } y_{i t}+\gamma_{4} k a t h \_d u m m y_{i t}+ \\
& \gamma_{5} \text { akth_dummy } y_{i t}+\vartheta_{i t}
\end{aligned}
$$

Dimana $N_{i t}$ adalah jumlah peserta pemilihan pada tahap evaluasi sebelum penetapan pemenang, estimate $_{\text {it }}$ merupakan size paket pengadaan (nilai HPS), prequalification_dummy $y_{i t}$ merupakan metode prakualifikasi, atkh_dummy $y_{i t}$ merupakan dummy pola evaluasi Administrasi-Teknis-HargaKualifikasi (ATHK), kath_dummy it adalah dummy pola evaluasi Kualifikasi-Administrasi-TeknisHarga (KATH), dan akth_dummy it merupakan dummy pola evaluasi Administrasi-KualifikasiTeknis-Harga (AKTH), serta $i$ menunjukan paket pekerjaan $i$ dan $t$ menunjukan waktu.

Selanjutnya, model regresi tahap kedua dapat ditulis sebagai berikut.

$$
\begin{aligned}
\text { Ratio }_{i t}= & \theta_{0}+\theta_{1} \widehat{N_{l t}}+\theta_{2} \text { scoring_dummy } \\
& \theta_{3} \text { price_dummy }_{i t}+ \\
& \theta_{4} \text { perpres1618_dummy }{ }_{i t}{ }^{+} \\
& \theta_{5} \text { scoring_perpres } 1618_{i t}{ }^{+} \\
& \theta_{6} \text { construction_dummy }{ }_{i t}{ }^{+} \\
& \theta_{7} \text { goods_dummy }{ }_{i t}+\theta_{8} \text { other_dummy }{ }_{i t}{ }^{+} \\
& \theta_{9} \text { boardconsultancy_dummy } \\
i t & +\varepsilon_{i t}
\end{aligned}
$$

Dimana $\widehat{N}_{i t}$ adalah jumlah peserta pemilihan pada tahap evaluasi sebelum penetapan pemenang yang telah diestimasi, scoring_dummy merupakan metode evaluasi dengan menggunakan kombinasi bobot antara bobot teknis dan bobot harga, price_dummy $y_{i t}$ merupakan metode evaluasi dengan menggunakan harga terendah, perpres1618_dummy ${ }_{i t}$ merupakan paket pekerjaan yang telah menggunakan Peraturan Presiden Nomor 16 Tahun 2018, scoring_perpres $1618_{i t}$ merupakan metode evaluasi kombinasi bobot teknis dan harga saat berlakunya Peraturan Presiden Nomor 16 Tahun 2018, construction_dummy it $_{\text {adalah pekerjaan }}$ konstruksi, goods_dummy ${ }_{i t}$ merupakan pengadaan barang, other_dummy $y_{i t}$ adalah jenis jasa lainnya, boardconsultancy_dummy ${ }_{i t}$ adalah jenis pengadaan jasa konsultansi badan usaha.

Pertimbangan penggunaan ketiga instrumen pada model regresi tahap pertama antara lain karena diduga jumlah peserta pemilihan pada tahap evaluasi terakhir sebagai hasil dari ketiga instrumen tersebut, dimana sebelum berada pada tahap evaluasi terakhir, peserta pemilihan akan melalui beberapa tahapan sebelumnya. Pertama, penyedia yang memasukkan penawaran akan mempertimbangkan nilai HPS pada paket pengadaan agar dapat berada pada tahap evaluasi terakhir. Selain itu, karena semakin besar nilai HPS pokja pemilihan akan mensyaratkan kualifikasi penyedia sesuai ijin usaha, kemampuan finansial, sumber daya, dan pengalaman, maka semakin besar nilai HPS kompetisi paket pekerjaan akan terbatas. Kedua, pola evaluasi yang digunakan untuk mengetahui tahapan evaluasi yang akan dilalui dan tahap evaluasi terakhir dan penilaian prakualifikasi sebagai tahapan yang telah dilalui oleh peserta pemilihan pada tahap evaluasi terakhir, dimana pada penilaian prakualifikasi ini dilaksanakan sebelum peserta pemilihan memasukan dokumen penawaran administrasi, teknis dan harga.

\section{HASIL PENELITIAN}

\subsection{Analisis Hasil}

\subsubsection{Hasil Estimasi OLS}

Hasil estimasi pengaruh jumlah peserta pemilihan pada tahap evaluasi sebelum penetapan pemenang terhadap rasio harga penawaran pemenang dan HPS menggunakan regresi Ordinary Least Square (OLS) sebagaimana pada Tabel 1. Berdasarkan hasil uji-F menunjukan bahwa Prob $>F$ bernilai 0.00, yang berarti bahwa secara statistik pada tingkat signifikansi 1 persen, seluruh variabel penjelas pada penelitian ini secara bersama-sama mempengaruhi rasio harga penawaran pemenang dan HPS. Adapun model tersebut memiliki Rsquared sebesar 0.194, yang menunjukkan variabel penjelas pada penelitian ini menjelaskan 19.4 persen varians pada variabel rasio harga penawaran pemenang dan HPS.

Lalu, untuk pengujian signifikansi dilakukan dengan cara melihat $p$-values pada masing-masing variabel penjelas. Hasil uji two-tail $p$-values menunjukkan bahwa variabel penjelas utama jumlah peserta pemillihan pada tahap evaluasi sebelum penetapan pemenang berpengaruh signifikan terhadap rasio harga penawaran 
pemenang dan HPS pada tingkat signifikansi 1 persen. Selain itu, variabel kontrol seperti metode evaluasi harga terendah, nilai HPS, dan jenis pengadaan pekerjaan konstruksi, pengadaan barang, jasa lainnya dan jasa konsultansi badan usaha berpengaruh signifikan terhadap rasio harga penawaran pemenang dan HPS pada tingkat signifikansi 1 persen, sedangkan size paket pengadaan dan metode evaluasi kombinasi bobot teknis dan harga tidak berpengaruh signifikan.

Tabel 1 Hasil Estimasi OLS Rasio Harga Penawaran Pemenang dan HPS

\begin{tabular}{|c|c|c|}
\hline Variabel Bebas & Coeff & Std. Err \\
\hline Jumlah Peserta Pemilihan & $-0.0194 * * *$ & $(0.000436)$ \\
\hline $\begin{array}{l}\text { Dummy Metode Penilaian Kualifikasi: } \\
\text { (1 = Prakualifikasi) }\end{array}$ & $-0.00522^{*}$ & $(0.00251)$ \\
\hline $\begin{array}{l}\text { Dummy Metode Evaluasi Penawaran: } \\
\text { Kombinasi Bobot Teknis dan Harga } \\
\text { (1 = Kombinasi Bobot Teknis dan Harga) }\end{array}$ & -0.0204 & $(0.0116)$ \\
\hline $\begin{array}{l}\text { Dummy Metode Evaluasi Penawaran: Harga } \\
\text { Terendah } \\
\text { (1 = Harga Terendah) }\end{array}$ & $-0.0147^{* * *}$ & $(0.00263)$ \\
\hline Size Paket Pengadaan (Nilai HPS) & $-1.30 \mathrm{e}-13$ & $(9.01 \mathrm{e}-14)$ \\
\hline \multicolumn{3}{|l|}{$\begin{array}{l}\text { Dummy Perpres } 16 / 2018 \\
\text { (1=Paket pengadaan yang menggunakan } \\
\text { Perpres } 16 / 2018)\end{array}$} \\
\hline $\begin{array}{l}\text { Dummy Metode Skor Kombinasi Teknis- } \\
\text { Harga Saat Berlaku Perpres 16/2018 } \\
\text { (1= Evaluasi Kombinasi Bobot Teknis-Harga } \\
\text { Pasca saat Berlaku Perpres 16/2018) }\end{array}$ & $-0.0147^{* * *}$ & $(0.00263)$ \\
\hline $\begin{array}{l}\text { Dummy Pola Evaluasi ATHK } \\
\text { (1 = Pola Evaluasi ATHK) }\end{array}$ & $0.00522^{* * *}$ & $(0.00158)$ \\
\hline $\begin{array}{l}\text { Dummy Pola Evaluasi ATKH } \\
\text { (1 = Pola Evaluasi ATKH) }\end{array}$ & $-0.00774^{*}$ & $(0.00305)$ \\
\hline $\begin{array}{l}\text { Dummy Pola Evaluasi KATH } \\
\text { (1 = Pola Evaluasi KATH) }\end{array}$ & $0.0248^{* * *}$ & $(0.00164)$ \\
\hline $\begin{array}{l}\text { Dummy Pekerjaan Konstruksi } \\
\text { (1 = Pekerjaan Konstruksi) }\end{array}$ & $-0.0221^{* * *}$ & $(0.00327)$ \\
\hline $\begin{array}{l}\text { Dummy Pengadaan Barang } \\
\text { (1 = Pengadaan Barang) }\end{array}$ & $-0.0239 * * *$ & $(0.00328)$ \\
\hline $\begin{array}{l}\text { Dummy Jasa Lainnya } \\
\text { (1 = Jasa Lainnya) }\end{array}$ & $-0.0662^{* * *}$ & $(0.00334)$ \\
\hline $\begin{array}{l}\text { Dummy Jasa Konsultansi Badan Usaha } \\
\text { (1 = Jasa Konsultansi Badan Usaha) }\end{array}$ & $-0.0315^{* * *}$ & $(0.00362)$ \\
\hline $\begin{array}{l}\text { Observasi } \\
\text { R-sq }\end{array}$ & $\begin{array}{c}82,560 \\
0.146\end{array}$ & $\begin{array}{c}82,560 \\
0.146\end{array}$ \\
\hline
\end{tabular}

Dependent Variable: Rasio Harga Penawaran Pemenang dan HPS

${ }^{*} \mathrm{p}<0.1,{ }^{* *} \mathrm{p}<0.05,{ }^{* * *} \mathrm{p}<0.01$

Pada variabel kontrol Pola Evaluasi, pola evaluasi KATH dan pola evaluasi ATHK berpengaruh signifikan terhadap rasio (pada tingkat signifikansi 1 persen), dan variabel kontrol pola evaluasi ATKH dan metode penilaian prakualifikasi berpengaruh signifikan pada tingkat signifikansi 10 persen terhadap rasio harga penawaran pemenang dan HPS. Dan untuk metode evaluasi kombinasi bobot teknis pasca Peraturan Presiden Nomor 16 Tahun 2018 berpengaruh signifikan terhadap rasio harga penawaran pemenang. Dari hasil estimasi OLS, jumlah peserta pemilihan memiliki hubungan negatif terhadap rasio harga penawaran pemenang dan HPS.

\subsubsection{Hasil Estimasi IV-2SLS}

Penelitian ini juga menggunakan instrumental variable dengan teknik estimasi 2SLS untuk mengurangi potensi bias akibat permasalahan endogeneity. Berdasarkan hasil uji endogeneity terlihat bahwa variabel jumlah peserta pemilihan tahap evaluasi terakhir adalah bersifat endogen. Hal ini ditunjukkan dari hasil uji J-Statistic yang menghasilkan $p$-value sebesar 0,000 yang artinya 
hipotesis null bahwa variabel jumlah peserta pemilihan tahap evaluasi terakhir bersifat eksogen berhasil ditolak, sehingga dapat disimpulkan bahwa variabel jumlah peserta pemilhan tahap evaluasi terakhir berhasil ditolak.

Seperti yang telah dijelaskan pada Bagian 4.2, penelitian ini menggunakan metode prakualifikasi, pola evaluasi (ATHK dan KATH) dan size paket pengadaan sebagai instrumental variable dalam menentukan jumlah peserta pemilihan tahap evaluasi terakhir yang berpengaruh secara tidak langsung pada rasio harga penawaran pemenang dan HPS. Hasil estimasi tahap pertama dan tahap kedua IV-2SLS terlihat pada Tabel 2 dan Tabel 3.

Tabel 2 Hasil Estimasi IV-2SLS Tahap Pertama

\begin{tabular}{|c|c|c|}
\hline Variabel Bebas & Coeff & Std. Err \\
\hline $\begin{array}{l}\text { Size Paket Pengadaan } \\
\text { (Nilai HPS) }\end{array}$ & $-7.06 e-13$ & $(5.40 e-13)$ \\
\hline $\begin{array}{l}\text { DummyPenilaian Kualifikasi } \\
\text { (1 = Prakualifikasi) }\end{array}$ & $0.299 * * *$ & $(0.0128)$ \\
\hline $\begin{array}{l}\text { DummyPola Evaluasi ATHK } \\
\text { (1= Pola Evaluasi ATHK) }\end{array}$ & $0.922^{* * *}$ & $(0.0244)$ \\
\hline $\begin{array}{l}\text { DummyPola Evaluasi KATH } \\
\text { (1= Pola Evaluasi KATH) }\end{array}$ & $-0.168^{* * *}$ & $(0.0248)$ \\
\hline $\begin{array}{l}\text { DummyPola Evaluasi AKTH } \\
\text { (1= Pola Evaluasi AKTH) }\end{array}$ & 0.0391 & $(0.0265)$ \\
\hline Observasi & 82,560 & 82,560 \\
\hline
\end{tabular}

Dependent Variable: Jumlah Peserta Pemilihan Tahap Evaluasi Terakhir

${ }^{*} \mathrm{p}<0.1,{ }^{* *} \mathrm{p}<0.05,{ }^{* * *} \mathrm{p}<0.01$

Berdasarkan Tabel 2 terlihat hubungan negatif antara jumlah peserta pemilihan dan size paket pengadaan. Besarnya paket pengadaan diduga menjadi pertimbangan peserta pemilihan untuk mendaftar agar dapat berada pada tahap evaluasi terakhir dan menjadi pemenang dalam paket pengadaan. Semakin besar nilai paket pengadaan, pokja pemilihan akan mensyaratkan kualifikasi tambahan yang meliputi ijin usaha, kemampuan finansial dan lain-lain serta penawaran teknis, kesesuaian harga dengan nilai dan kompleksitas paket pengadaan sehingga peserta yang berada pada tahap terakhir meupakan peserta yang telah melalui beberapa tahapan evaluasi. Hal ini menyebabkan semakin besar nilai paket pengadaan, maka semakin terbatas juga kompetisi yang terjadi karena jumlah pelaku usaha yang memiliki kualifikasi atau kemampuan teknis hanya sedikit. Pemerintah juga mengatur bahwa paket pengadaan dengan nilai pengadaan di bawah 2,5 miliar rupiah diprioritaskan bagi usaha kecil.

Secara umum, dapat terlihat bahwa terdapat pengaruh dari jumlah peserta pemilihan terhadap rasio harga penawaran pemenang dan HPS. Hasil ini konsisten dengan dengan hasil estimasi pada metode OLS. Meskipun demikian, hasil estimasi IV2SLS lebih menggambarkan pengaruh jumlah peserta pemilihan pada tahap evaluasi terakhir sebelum penetapan pemenang karena diduga nilai paket pengadaan, pola evaluasi dan metode prakualifikasi tidak secara langsung mempengaruhi rasio harga penawaran pemenang dan HPS melainkan melalui variabel peserta pemilihan pada tahap evaluasi terakhir.
Berdasarkan Tabel 2 terlihat bahwa ketika jumlah peserta pemilihan pada tahap evaluasi terakhir bertambah sebanyak 1 peserta pemilihan, maka akan menurunkan rasio harga penawaran dan HPS sebesar 0.0335 atau menghemat belanja pengadaan pemerintah sebesar 3.35 persen atas nilai HPS. Adapun pada penelitian ini range HPS yang digunakan berada di angka Rp24.486.400 sampai dengan Rp2.135.154.241.000, atau secara rata-rata nilai HPS sebesar 2.99 miliar rupiah.

\subsection{Diskusi}

Tabel 3 menunjukan hasil regresi tahap kedua dari IV-2SLS yang menjelaskan pengaruh jumlah peserta pemilihan tahap evaluasi terakhir sebelum penetapan pemenang terhadap rasio harga penawaran pemenang dan HPS. Hasil estimasi menunjukan bahwa jumlah peserta pemilihan pada tahap evaluasi sebelum penetapan pemenang berpengaruh signifikan dan negatif terhadap rasio harga penawaran pemenang dan HPS, dimana setiap bertambahnya 1 peserta pemilihan cenderung mengurangi rasio harga penawaran pemenang dan HPS sebesar 0.0335. Artinya setiap bertambahnya satu peserta pemilihan dapat menurunkan harga penawaran pemenang sebesar 3.35 persen atas nilai HPS atau menghemat belanja pengadaan pemerintah pada Kementerian/ Lembaga melalui tender dan seleksi sebesar 3.35 persen. Hal ini menunjukan bahwa semakin kompetitif suatu paket tender dan seleksi maka secara biaya dapat mengurangi belanja barang jasa pemerintah. 
Tabel 3 Hasil Estimasi Tahap Kedua IV-2SLS: Pengaruh Jumlah Peserta Pemilihan Tahap Sebelum Penetapan Pemenang terhadap Rasio Harga Penawaran Pemenang dan HPS

\begin{tabular}{|c|c|c|}
\hline Variabel Bebas & Coeff & Std. Err \\
\hline $\begin{array}{l}\text { Jumlah Peserta Tahap Evaluasi Sebelum } \\
\text { Penetapan Pemenang }\end{array}$ & $-0.0355^{* * *}$ & $(0.000674)$ \\
\hline $\begin{array}{l}\text { Dummy Metode Evaluasi Penawaran: } \\
\text { Kombinasi Bobot Teknis dan Harga } \\
\text { (1= Evaluasi Kombinasi Bobot Teknis dan } \\
\text { Harga) }\end{array}$ & -0.00922 & $(0.00107)$ \\
\hline $\begin{array}{l}\text { Dummy Metode Evaluasi Penawaran: } \\
\text { Harga Terendah } \\
\text { (1= Evaluasi Harga Terendah) }\end{array}$ & $-0.0206^{*}$ & $(0.0102)$ \\
\hline $\begin{array}{l}\text { Dummy Berlakunya Perpres Nomor } 16 \\
\text { Tahun } 2018 \\
\text { (1=Berlakunya Perpres Nomor } 16 \text { Tahun } \\
\text { 2018) }\end{array}$ & $-0.00623^{* * *}$ & $(0.00119)$ \\
\hline $\begin{array}{l}\text { Dummy Metode Evaluasi Penawaran } \\
\text { Kombinasi Bobot Teknis dan Harga saat } \\
\text { Perpres Nomor } 16 \text { Tahun } 2018 \\
\text { (1= Evaluasi Kombinasi Bobot Teknis- } \\
\text { Harga saat Perpres } 16 / 2018 \text { ) }\end{array}$ & 0.00216 & $(0.00291)$ \\
\hline $\begin{array}{l}\text { Dummy Pekerjaan Konstruksi } \\
\text { (1 = Pekerjaan Konstruksi) }\end{array}$ & $-0.0197^{* * *}$ & $(0.00310)$ \\
\hline $\begin{array}{l}\text { Dummy Pengadaan Barang } \\
\text { (1=Pengadaan Barang) }\end{array}$ & $-0.0170^{* * *}$ & $(0.00315)$ \\
\hline $\begin{array}{l}\text { Dummy Jasa Lainnya } \\
\text { (1=Jasa Lainnya) }\end{array}$ & $-0.0638^{* * *}$ & $(0.00319)$ \\
\hline $\begin{array}{l}\text { Dummy Jasa Konsultansi Badan Usaha } \\
\text { (1=Jasa Konsultansi Badan Usaha) }\end{array}$ & $-0.0316^{* * *}$ & $(0.00327)$ \\
\hline Observasi & 82,560 & 82,560 \\
\hline
\end{tabular}

Dependent Variable: Rasio Harga Penawaran Pemenang dan HPS.

${ }^{*} \mathrm{p}<0.1,{ }^{* *} \mathrm{p}<0.05,{ }^{* * *} \mathrm{p}<0.01$

Dengan semakin banyaknya jumlah peserta pemilihan, adanya informasi asimetris terhadap pesaing, serta adanya kompetisi, maka koordinasi akan lebih sulit dilakukan dan coordination cost menjadi mahal. Hal tersebut menjadi insentif bagi peserta pemilihan untuk menawarkan harga terendah agar dapat menjadi pemenang pada paket tender/seleksi tersebut. Hal ini juga menunjukan bahwa lingkungan yang kompetitif tidak hanya diperlukan dan terjadi pada saat tahap awal sebagaimana penelitian sebelumnya (Estache \& Iimi, 2008; Iimi, 2006; Ishii, 2009; Onur, Özcan, \& Taş, 2012; Onur \& Tas, 2019), tetapi juga pada tahap evaluasi sebelum penetapan pemenang. Hal ini terkonfirmasi pada bukti deskriptif pada Gambar 1 yang menunjukan terjadinya penurunan rata-rata rasio antara harga penawaran pemenang dan HPS ketika jumlah peserta pemilihan bertambah.

Gambar 1 Hubungan Jumlah Peserta Pemilihan dan Rata-rata Rasio Harga Penawaran Pemenang dan HPS

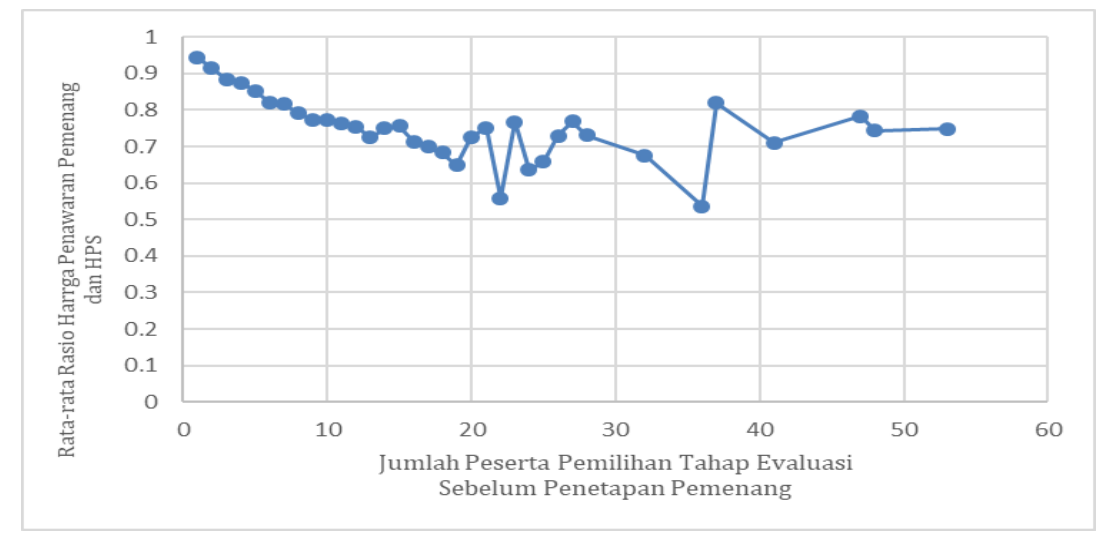

Sumber: Hasil Scraping Website LPSE, diolah Penulis 
Sesuai dengan tujuan penelitian, pengaruh jumlah peserta pemilihan pada tahap evaluasi terakhir sebelum penetapan pemenang adalah negatif. Artinya, semakin banyak jumlah peserta pemilihan, maka harga penawaran pemenang atau rasio harga penawaran pemenang dan HPS akan menurun.

Hasil estimasi menggunakan metode OLS menunjukan hal yang sama, yaitu adanya pengaruh negatif dari jumlah peserta pemilihan pada tahap evaluasi terakhir terhadap rasio harga penawaran pemenang dan HPS. Dengan mempertimbangkan adanya kemungkinan bias yang dihasilkan oleh estimasi OLS akibat endogeneity, maka estimasi menggunakan IV-2SLS yang menghasilkan nilai koefisien yang relatif sama dengan metode OLS namun dengan bias yang telah direduksi.

Penelitian ini juga menemukan adanya hubungan negatif antara metode evaluasi penawaran harga terendah dan rasio harga penawaran pemenang dan HPS. Dengan adanya informasi yang berbeda antara satu peserta dengan peserta pemilihan lainnya menyebabkan terjadinya informasi asimetris dan ketidakpastian memenangkan tender/seleksi (Matthews, 1987; McAfee \& McMillan, 1987). Ketika menghadapi informasi asimetris dan ketidakpastian tersebut para peserta pemilihan akan cenderung menawarkan harga terendah, dengan memenuhi persyaratan teknis terlebih dahulu sehingga menyebabkan rasio antara harga penawaran pemenang dan HPS menurun.
Selain itu, penelitian ini juga menemukan adanya hubungan negatif pada rasio harga penawaran pemenang dengan HPS sejak diberlakukannya Peraturan Presiden Nomor 16 Tahun 2018. Ditinjau secara deskriptif, sebelum diberlakukannya Peraturan Presiden Nomor 16 Tahun 2018 secara rata-rata nilai rasionya adalah 91.45 persen atau menghemat belanja pengadaan pemerintah sebesar 8.55 persen. Setelah aturan tersebut diterapkan, secara rata-rata rasionya meningkat menjadi 92.12 persen atau menghemat belanja pengadaan pemerintah 7.88 persen. Hal ini menunjukan bahwa secara statistik, penghematan yang dihasilkan sebelum diberlakukannya aturan ini lebih efisien dibandingkan setelah aturan ini diberlakukan.

\section{Ditinjau dari Nilai HPS}

Tabel 4 menunjukan hasil robustness analysis berdasarkan nilai paket pengadaan. Berdasarkan Tabel 4, terlihat bahwa pada ketiga range nilai paket pengadaan, terdapat hubungan negatif antara jumlah peserta pemilihan dan rasio harga penawaran pemenang dan HPS, walaupun untuk nilai paket diatas 10 miliar tidak signifikan terhadap variabel dependen. Dari range nilai tersebut, terlihat bahwa efek kompetisi lebih besar terjadi pada nilai paket pengadaan dengan nilai kurang dari 2.5 miliar rupiah dibandingkan dengan lainnya. Hal ini kemungkinan terjadi karena jumlah peserta pemilihan yang mengikuti proses pemilihan untuk nilai paket di bawah 2.5 miliar lebih banyak dibandingkan yang lain.

Tabel 4 Hasil Estimasi IV-2SLS Berdasarkan Nilai Paket Pengadaan

\begin{tabular}{lcccc}
\hline \multirow{2}{*}{ Variabel Bebas } & \multicolumn{4}{c}{ Nilai HPS } \\
\cline { 2 - 5 } & $<2.5$ Miliar & $\begin{array}{c}\text { Antara 2.5 M } \\
\text { s/d 5 M }\end{array}$ & $\begin{array}{c}\text { Antara 5 M } \\
\text { s/d 10 M }\end{array}$ & $>$ 10 Miliar \\
\hline Jumlah Peserta Tahap & $\mathbf{- 0 . 0 3 5 1 ^ { * * * }}$ & $\begin{array}{c}\mathbf{- 0 . 0 3 3 1 * * *} \\
\text { Evaluasi Sebelum }\end{array}$ & $\mathbf{- 0 . 0 2 2 7 ^ { * * * }}$ & $\mathbf{- 0 . 0 2 9 4 * * *}$ \\
$\begin{array}{l}\text { Penetapan Pemenang } \\
\text { Observasi }\end{array}$ & 64,824 & 8,692 & 4,782 & $\mathbf{( 0 . 0 0 6 6 5 )}$ \\
\hline
\end{tabular}

Dependent Variable: Rasio Harga Penawaran Pemenang dan HPS. Hasil menggunakan estimator IV-2SLS dengan standard error robust. ${ }^{*} \mathrm{p}<0.1,{ }^{* *} \mathrm{p}<0.05,{ }^{* * *} \mathrm{p}<0.01$

Sebagaimana aturan pengadaan pemerintah di Indonesia, nilai paket pengadaan di bawah 2.5 miliar diprioritaskan bagi usaha kecil sehingga pada nilai paket tersebut jumlah peserta yang mengikuti seleksi/tender sebagian besar merupakan pelaku usaha kecil yang jumlahnya mungkin lebih banyak dari usaha non kecil.

\section{KESIMPULAN DAN SARAN}

Pada penelitian ini, kami menginvestigasi pengaruh jumlah peserta pemilihan pada tahap evaluasi sebelum penetapan pemenang terhadap rasio harga penawaran pemenang dan HPS pada paket tender dan seleksi pada LPSE Kementerian/Lembaga di Indonesia periode tahun 2008 s.d. bulan Maret 2020. Kami menggunakan data unik paket pengadaan yang dipublikasikan pada 402 website LPSE Kementerian/Lembaga di Indonesia. Kami menemukan bahwa jumlah peserta pemilihan pada tahap evaluasi sebelum penetapan pemenang berpengaruh signifikan dan negatif terhadap rasio antara harga penawaran pemenang dan HPS, yang mengindikasikan bahwa competitive bidding pada tahap evaluasi sebelum penetapan pemenang meningkatkan efektivitas tender dan seleksi pengadaan pemerintah dan 
mengurangi belanja pemerintah untuk pengadaan barang jasa pemerintah pada LPSE Kementerian Lembaga di Indonesia.

Hasil estimasi OLS memberikan bukti adanya pengaruh jumlah peserta pemilihan pada tahap evaluasi terakhir sebelum penetapan pemenang terhadap rasio harga penawaran pemenang dan HPS. Jumlah peserta pemilihan pada tahap evaluasi terakhir memberikan pengaruh negatif terhadap rasio harga penawaran pemenang dan HPS.

Kami juga menemukan bahwa metode evaluasi harga terendah dapat menurunkan rasio antara harga penawaran pemenang dan HPS. Pada metode evaluasi ini, antara sesama peserta pemilihan saling mengalami informasi tidak sempurna terkait teknis dan harga yang ditawarkan. Hal ini menyebabkan peserta pemilihan akan menawarkan teknis sesuai dengan persyaratan yang diberikan pokja pemilihan dan menawarkan harga terendah sehingga pokja pemilihan memperoleh harga penawaran pemenang terendah dan mengurangi belanja pengadaan pemerintah. Namun disatu sisi, penggunaan metode evaluasi kombinasi pembobotan teknis dan harga dan pemberlakuan aturan perubahan proporsi bobot teknis dan harga pasca berlakunya Peraturan Presiden Nomor 16 Tahun 2018 tidak memiliki efek terhadap rasio harga penawaran pemenang dan HPS. Tetapi secara keseluruhan, berlakunya Peraturan Presiden Nomor 16 Tahun 2018 mengakibatkan turunnya rasio harga penawaran dan HPS.

Setelah menggunakan metode IV-2SLS untuk mengurangi potensi bias akibat endogeneity, penelitian ini menemukan adanya pengaruh dari jumlah peserta pemilihan tahap evaluasi terakhir terhadap rasio harga penawaran pemenang dan HPS, di mana setiap bertambahnya jumlah peserta pemilihan sebanyak satu peserta akan mengurangi rasio sebesar 0.0335 satuan atau menghemat belanja pengadaan melalui tender atau seleksi sebesar 3.35 persen terhadap nilai HPS. Selain itu, kami juga menemukan adanya pengaruh tidak langsung dari nilai paket pengadaan, metode prakualifikasi dan pola evaluasi terhadap jumlah peserta.

\section{KETERBATASAN PENELITIAN}

Penelitian ini masih sangat terbatas karena masih terdapat beberapa website LPSE Kementerian/Lembaga yang tidak berhasil discraping sehingga penulis tidak dapat menangkap secara keseluruhan kondisi tender dan seleksi pada pengadaan pemerintah Kementerian/ Lembaga di Indonesia. Selain itu, data masih terbatas pada level paket tender dan seleksi karena data kualifikasi dan penawaran pada tingkat perusahaan atau peserta pemilihan tidak dipublikasi secara umum pada website LPSE. Oleh karena itu, penelitian ini hanya mencakup data paket tender dan seleksi yang berhasil diperoleh dengan teknik website scraping dan untuk metode pemilihan tender, seleksi, lelang sederhana, lelang pemilihan langsung, lelang umum, seleksi umum dan seleksi sederhana pada tahun 2008 sampai dengan bulan Maret 2020.

\section{DAFTAR PUSTAKA}

Anton, J. J., \& Yao, D. A. (1992). Coordination in split award auctions. The Quarterly Journal of Economics, 107(2), 681-707.

Asker, J., Cantillon, E. (2010). Procurement when price and quality matter. RAND Journal of Economics, 41(1), 1-34.

Asker, J., \& Cantillon, E. (2008). Properties of scoring auctions. RAND Journal of Economics, 39, 69-85.

Bajari, P., \& Ye, L. (2003). Deciding between competition and collusion. Review of Economics and Statistics, 85, 971-989

Bag, P. K., \& Li, J. (2014). Bid coordination in splitaward procurement: The buyer need not know anything. Economics Letters, 124(1), 143-146.

Bichler, M. (2000). An experimental analysis of multi-attribute auctions. Decision Support Systems, 29(3), 249-268.

Blume, A., \& Heidhues, P. (2006). Private monitoring in auctions. Journal of Economic Theory, 131(1), 179-211.

Che, Y.-K. (1993). Design competition through multidimensional auctions. The RAND Journal of Economics, 24(4), 668.

Chen-Ritzo, C.-H., Harrison, T. P., Kwasnica, A. M., \& Thomas, D. J. (2005). Better, faster, cheaper: an experimental analysis of a multiattribute reverse auction mechanism with restricted information feedback. Management Science, 51(12), 1753-1762.

Compte, O., Lambert-Mogiliansky, A., \& Verdier, T. (2005). Corruption and competition in procurement auction. The RAND Journal of Economics, 36(1), 1-15

De Silva, D. G., Kosmopoulou, G., \& Lamarche, C. (2009). The effect of information on the bidding and survival of entrants in procurement auctions. Journal of Public Economics, 93(1-2), 56-72.

Estache, A., \& Iimi, A. (2008). Procurement Efficiency for infrastructure development and financial needs reassessed. Policy Research 


\section{Working Paper. https://doi.org/10.1596/ 1813-9450-4662}

Fan, C., \& Wolfstetter, E. (2008). Procurement with costly bidding, optimal shortlisting, and rebates. Economics Letters, 98(3), 327-334.

Gupta, S. (2002). Competition and collusion in a government procurement auction market. Atlantic Economic Journal, 30(1), 13-25.

Iimi, A. (2006). Auction reforms for effective official development assistance. Review of Industrial Organization, 28(2), 109-128.

Ishii, R. (2009). Favor exchange in collusion: Empirical study of repeated procurement auctions in Japan. International Journal of Industrial Organization, 27(2), 137-144.

Jääskeläinen, J., \& Tukiainen, J. (2019). Anatomy of public procurement. SSRN Electronic Journal. https://doi.org/10.2139/ssrn.3372135

Keputusan Deputi Bidang Pengembangan Strategi dan Kebijakan Lembaga Kebijakan Pengadaan Barang/Jasa Pemerintah Nomor 3 Tahun 2018 tentang Standar Dokumen Pemilihan Melalui Tender, Seleksi, dan Tender Cepat Untuk Pengadaan Barang/Jasa Lainnya/Jasa Konsultansi

Keputusan Presiden Nomor 80 Tahun 2003 tentang Pedoman Pelaksanaan Pengadaan Barang/Jasa Pemerintah

Lembaga Kebijakan Barang Jasa Pemerintah. (2018). Profil pengadaan barang/jasa pemerintah tahun 2017. Jakarta: LKPP

Lembaga Kebijakan Barang Jasa Pemerintah. (2019). Profil pengadaan barang/jasa pemerintah tahun 2018. Jakarta: LKPP

Matthews, S. (1987). Comparing auctions for risk averse buyers: a buyer's point of view. Econometrica: Journal of The Econometric Society, 633-646

McAfee, R.P., \& McMillan, J. (1987). Auction and bidding. Journal of Economic Literature, 25(2), 699-738

McAfee, R. P., \& McMillan, J. (1992). Bidding rings. The American Economic Review, 82(3), 579599.

Menezes, F. M., \& Monteiro, P. K. (2006). Corruption and auctions. Journal of Mathematical Economics, 42(1), 97-108.

OECD. (2016). Preventing corruption in public procurement. Paris: OECD Publishing.

Ondestal, S., \& Van de Meerendonk, A. (2008). How (not) to design procurement mechanisms: A laboratory experiment. Paper presented In 3rd International Public Procurement Conference Proceedings.

Onur, İ., Özcan, R., \& Taş, B. K. O. (2012). Public procurement auctions and competition in Turkey. Review of Industrial Organization, 40(3), 207-223.

Onur, I., \& Tas, B. K. O. (2019). Optimal bidder participation in public procurement auctions. International Tax and Public Finance, 26(3), 595-617.

Padhi, S. S., \& Mohapatra, P. K. J. (2011). Detection of collusion in government procurement auctions. Journal of Purchasing and Supply Management, 17(4), 207-221.

Porter, R., \& Zona J. (1993). Detection of bid rigging in procurement auction. Journal of Political Economy, 101 (3), 518-53

Peraturan Presiden Nomor 54 Tahun 2010 tentang Pengadaan Barang Jasa Pemerintah

Peraturan Presiden Nomor 4 Tahun 2015 tentang Perubahan Keempat atas Peraturan Presiden nomor 54 Tahun 2010

Peraturan Presiden Nomor 16 Tahun 2018 tentang Pengadaan Barang Jasa Pemerintah

Peraturan Kepala Lembaga Kebijakan Pengadaan Barang Jasa Pemerintah Nomor 15 Tahun 2012 tentang Standar Dokumen Pengadaan Barang Jasa Pemerintah

Peraturan Lembaga Kebijakan Barang Jasa Pemerintah Nomor 9 Tahun 2018 tentang Pedoman Pelaksanaan Pengadaan Barang/Jasa Melalui Penyedia

Peraturan Menteri Pekerjaan Umum dan Perumahan Rakyat Nomor 07/PRT/M/2011 tentang Standar dan Pedoman Pengadaan Pekerjaan Konstruksi dan Jasa Konsultansi

Peraturan Menteri Pekerjaan Umum dan Perumahan Rakyat Nomor 07/PRT/M/2019 tentang Standar dan Pedoman Pengadaan Jasa Konstruksi Melalui Penyedia

Wolfstetter, E. (1999). Topics in microeconomics: industrial organization, auctions, and incentives. Cambridge: Cambridge University Press 